\title{
Pythium brassicum sp. nov.: A Novel Plant Family-Specific Root Pathogen
}

\author{
Michael E. Stanghellini, Mojtaba Mohammadi, Helga Förster, and James E. Adaskaveg, Department of Plant Pathology and \\ Microbiology, University of California, Riverside 92521
}

\begin{abstract}
Stanghellini, M. E., Mohammadi, M., Förster, H., and Adaskaveg, J. E. 2014. Pythium brassicum sp. nov.: A novel plant family-specific root pathogen. Plant Dis. 98:1619-1625.

Roots of stunted broccoli plants (Brassica oleracea) from the Palo Verde Valley, CA, were observed at various stages of decay. A species of Pythium with large spiny oogonia was microscopically observed and consistently isolated from decayed roots. Isolates produced spherical, intercalary sporangia (average $34.5 \mu \mathrm{m}$ in diameter) and aplerotic oospores (average $37.3 \mu \mathrm{m}$ in diameter) in oogonia (average $47.4 \mu \mathrm{m}$ in diameter) bearing numerous conical spines (average $8.5 \mu \mathrm{m}$ in height and $5.5 \mu \mathrm{m}$ basal width) with blunt apices. A representative broccoli isolate (P1) had a 99\% internal transcribed spacer (ITS) sequence similarity with Pythium jasmonium (nom. inval., GenBank AF216654.1), a species which has not been formally described. Three other accessions in GenBank also carry the specific epithet of $P$. jasmonium and were originally isolated from diseased plants in the family Brassicaceae. In our study, these isolates were pathogenic on broccoli and morpho-

logically similar to P1. P1 was pathogenic to 10 cultivated and 12 wild plants in the family Brassicaceae but not to 18 species of cultivated plants belonging to nine other plant families. Mycelial growth of our isolates occurred between $<10$ and $35^{\circ} \mathrm{C}$, with an optimum of $25^{\circ} \mathrm{C}$ (maximum growth rate $25 \mathrm{~mm} /$ day). Our broccoli isolates are related to other species in subclade B of clade J. Members of subclade B include $P$. mastophorum, $P$. uncinulatum, $P$. buismaniae, $P$. polymastum, and $P$. megalacanthum. However, the broccoli isolates, in addition to all those in GenBank that carry the specific epithet of $P$. jasmonium, possess unique ITS, $\beta$-tubulin, and cox 1 sequences that are sufficiently different from other species in subclade B to justify status as a new species. We propose that isolates previously designated as $P$. jasmonium (nom. inval.) be renamed as P. brassicum sp. nov. based on their apparent plant family-specific pathogenicity.
\end{abstract}

Pythium spp. are members of the kingdom Stramenopila: phylum Oomycota and many are plant pathogens of economic importance in agriculture. Commonly, they cause damping-off diseases of emerging seedlings in greenhouses and in agricultural fields but some species can also cause root diseases of older plants. Pythium spp. tend to be nonspecific in their host range and many species can infect a large number of hosts (e.g., Pythium ultimum with 719 host records), whereas some species such as $P$ graminicola and $P$. arrhenomanes are primarily pathogens of graminaceous hosts $(8,10,12)$.

In late October 2011, severely stunted broccoli plants (Brassica oleracea var. italica), were submitted for diagnosis from the Palo Verde Valley of California. This desert valley is a vegetable cropgrowing region and part of the lower Colorado River Basin along the eastern border of southern California adjacent to Arizona. The 30-ha furrow-irrigated crop had been planted in early September and, after 6 to 7 weeks, over $50 \%$ of the plants were declining in the field and showing root rot symptoms.

A Pythium sp. was isolated and was initially thought to be $P$. polymastum based on morphological features. $P$. polymastum has never been associated with root rot of any field-grown crop in California; however, the pathogen was reported as the cause of damping-off of broccoli and cauliflower seedlings in greenhouses in California in 1998 (1). At first, it was thought that the pathogen could have been introduced into the field on infected nursery stock; however, the broccoli crop had been direct seeded into the field.

Corresponding author: M. Stanghellini;

E-mail: michael.stanghellini@ucr.edu

Accepted for publication 13 May 2014.

http://dx.doi.org/10.1094/PDIS-03-14-0285-RE

(C) 2014 The American Phytopathological Society
The unusual field occurrence and the association of this particular species of Pythium with a major crop in California prompted this investigation.

Phylogenetic analysis of internal transcribed spacer (ITS) sequence data divided known Pythium spp. into 11 major clades $(5,9)$. Clade J contains two subclades, with $P$. nunn, $P$. orthogonon, $P$. acanthophoron, $P$. perplexum, $P$. nodosum, and $P$. cystogenes in one subclade (herein referred to as subclade A) and $P$. buismaniae, $P$. polymastum, $P$. uncinulatum, $P$. mastophorum, $P$. megalacanthum, and $P$. jasmonium in the other subclade (herein referred to as subclade B) $(5,9)$. The species in subclade A do not have many common morphological characteristics, whereas species in subclade $\mathrm{B}$ are morphologically distinct, with large oogonia ornamented with spines and thick-walled oospores. Oogonia and oospores of the Pythium spp. from our broccoli isolations have the morphological characteristics of species in subclade B of clade $\mathrm{J}$.

The objectives of this study were to clarify the identity and characterize the Pythium spp. from broccoli using morphological and molecular methods, as well as determine mycelial growth over a range of temperatures and determine the pathogenicity and host range of the isolates from broccoli.

\section{Materials and Methods}

Isolations from root samples and culturing of Pythium spp. Four stunted broccoli plants from three widely separated locations (North, West, and South) within a 30-ha commercial broccoli field were collected. Ten necrotic roots were excised from each stunted plant, washed in running tap water for $10 \mathrm{~min}$, blotted dry, plated onto $1.5 \%$ water agar, and incubated at $25^{\circ} \mathrm{C}$. Hyphae emerging from the roots were transferred to $10 \%$ clarified V8 juice (V8C) agar medium for identification.

Three isolates from broccoli (P1, P2, and P3) and five reference isolates identified as $P$. jasmonium based on ITS sequence information in GenBank, their reference numbers, host, and year of isolation are listed in Table 1. Six isolates (i.e., P1, CBS 101876, 
PPR18402, PPRI8404, MAFF725020, and MAFF725021) were employed for most of the studies reported herein and will be collectively referred to hereafter as Pj6. Additionally, a reference culture of $P$. polymastum (CBS 811.7) was used in some studies. Stock cultures of all isolates were maintained on $10 \%$ V8C agar.

Morphological characteristics of Pythium isolates. For these studies, all isolates were grown in $10 \%$ V8C broth for 14 days. In total, 50 measurements were made of morphological features of sexual spores of all Pj6 isolates. Asexual structures (i.e., hyphal swellings and sporangia) were not produced by any of the isolates in $10 \%$ V8C broth. However, asexual structures were occasionally and sparingly formed in water agar adjacent to broccoli roots colonized by isolates P1 and PPRI8404 in the pathogenicity studies described below.

Growth-temperature studies. A 5-mm-diameter disk of each $\mathrm{Pj} 6$ isolate from a 4-day-old culture was placed at the perimeter of three replicate petri plates containing $10 \%$ V8C agar. Plates were incubated at $10,15,20,25,30$, or $35^{\circ} \mathrm{C}$ in the dark. At 24 -h intervals, the radial growth of the developing colony was measured and the mean of three consecutive measurements per plate was used to estimate the daily growth rate at the various temperatures. Additionally, colony morphology and hyphal widths were recorded. The experiment was repeated once.

Pathogenicity and host range studies. In a greenhouse pathogenicity test, 2-week-old broccoli seedlings reared in Rockwool starter cubes were individually transplanted into 10 -cm-diameter pots containing steam-pasteurized University of California (UC) mix amended with $2 \mathrm{~g}$ of P1-colonized millet seed. Control plants were transplanted into pots containing UC mix amended with $2 \mathrm{~g}$ of autoclaved millet seed. There were four replications for each treatment. Fresh shoot weights were recorded 21 (first experiment) or 28 (second experiment) days after inoculation. Roots from inoculated and noninoculated plants were randomly collected, examined at $\times 400$ magnification for oospores, and plated onto water agar medium.

In laboratory pathogenicity tests, 10 to 12 seeds of selected plant genera and species (Table 2) were sown on $1.5 \%$ water agar in 9$\mathrm{cm}$-diameter petri dishes. Upon radicle emergence, a 7-mm-diameter plug of a 48-h-old 10\% V8C agar culture of selected isolates of the Pythium spp. mentioned above was placed in the center of the plate. This method provided the pathogen with a food base sufficient to support vegetative growth across the plate within $48 \mathrm{~h}$ at $24^{\circ} \mathrm{C}$. Data on postemergence root rot and seedling death or stunting were recorded after 10 to 14 days of incubation in a growth chamber at $24^{\circ} \mathrm{C}$ with a 12 -h photoperiod. Shoot and root length and tissue fresh weights were measured. Disease rating of each seedling was recorded as follows: $0=$ no evidence of root rot or shoot stunting, 1 = slight tap root discoloration, 2 = severe stunting or necrosis of tap root and stunting of shoot, and $3=$ plant dead. Three replicate petri dishes were used for each isolate and plant species and the experiment was repeated once.

DNA extraction, amplification, and sequencing. Pj6 isolates and two additional isolates from broccoli (P2 and P3) were cultured in $10 \mathrm{ml}$ of $\mathrm{V} 8 \mathrm{C}$ broth for 7 days at $25^{\circ} \mathrm{C}$. DNA was extracted (17) and $30 \mathrm{ng}$ was used as a template for amplification of the nuclear ribosomal internal transcribed spacer ITS (ITS1, 5.8 S rRNA, ITS2) region (1,000 to $1,100 \mathrm{bp}$ in size), and partial $\beta$-tubu- lin (658 bp in size) and mitochondrial cytochrome c oxidase subunit I (coxI) genes ( $727 \mathrm{bp}$ in size). The ITS universal primers were ITS1 (5'-TCCGTAGGTGAACCTGCGG-3') and ITS4 (5'-TCC TCCGCTTATTGATATGC-3') $(9,16)$. The $\beta$-tubulin gene primer pair was forward BT5 (5'-GTATCATGTGCACGTACTCGG-3') and reverse BT6 (5'-CAAGAAAGCCTTACG ACGGA-3') (12). The coxI primer pair was forward (OomCoxI-Levup (5'-TCA WCWMGATGGCTTTTTTCAAC- $3^{\prime}$ ) and reverse (FM85mod $5^{\prime}$ RRHWACKTGACTDATRATA CCAAA-3') (10).

Table 2. Pathogenicity of broccoli isolate P1 on cultivated and noncultivated plants

\begin{tabular}{|c|c|c|}
\hline Plants & Common name & $\begin{array}{l}\text { Disease } \\
\text { rating }\end{array}$ \\
\hline \multicolumn{3}{|l|}{ In the family Brassicaceae } \\
\hline \multicolumn{3}{|l|}{ Cultivated } \\
\hline Brassica oleracea var. acephala & Kale & 3 \\
\hline B. oleracea var. botrytis & Cauliflower & 3 \\
\hline B. oleracea var. capitata & Cabbage & 3 \\
\hline B. oleracea var. gemmifera & Brussel spouts & 3 \\
\hline B. oleracea var. italica & Broccoli & 3 \\
\hline B. rapa var. rapa & Turnip & 3 \\
\hline B. rapa var. ruvo & Rapini & 3 \\
\hline Lepidium sativum & Cress & 2.4 \\
\hline Lobularia maritima & Sweet alyssum & 2.8 \\
\hline Raphanus sativus & Radish & 3 \\
\hline \multicolumn{3}{|l|}{ Noncultivated } \\
\hline Arabidopsis thaliana $(\mathrm{C} 24)$ & Thale cress & 3 \\
\hline B. nigra & Black mustard & 3 \\
\hline B. rapa & Field mustard & 2.6 \\
\hline B. tournefortii & Sahara mustard & 3 \\
\hline Cardaria draba & Hoary cress & 3 \\
\hline C. pubescens & Hairy whitetop & 2.3 \\
\hline Hirschfeldia incana & Shortpod mustard & 3 \\
\hline Sinapis arvensis & Charlock mustard & 3 \\
\hline Sisymbrium erysimoides & Mediterranean rocket & 3 \\
\hline S. irio & London rocket 3 & \\
\hline S. officinale & Hedge mustard & 3 \\
\hline S. orientale & Oriental hedge mustard & 3 \\
\hline \multicolumn{3}{|l|}{ In other families } \\
\hline Bellis perennis & Daisy & 0.3 \\
\hline Bouteloua gracilis & Blue grama grass & 0 \\
\hline Capsicum anпиит & Pepper & 0 \\
\hline Cucumis melo & Cantaloupe & 0 \\
\hline C. sativus & Cucumber & 0 \\
\hline Daucus carota & Carrot & 0 \\
\hline Gypsophila paniculata & Baby's breath & 0 \\
\hline Gossypium hirsutum & Cotton & 0 \\
\hline Lactuca sativa & Lettuce & 0 \\
\hline Linum usitatissiumит & Fax & 0 \\
\hline Lupinus perennis & Lupine & 0 \\
\hline Medicago sativa & Alfalfa & 0 \\
\hline Nicotiana tabacum & Tobacco & 0.2 \\
\hline Ocimum basilicum & Sweet basil & 0 \\
\hline Solanum lycopersicum & Tomato & 0 \\
\hline Triticum aestivum & Wheat & 0 \\
\hline Vinca minor & Dwarf periwinkle & 0 \\
\hline Zea mays & Sweet corn & 0 \\
\hline
\end{tabular}

${ }^{a}$ Disease rating was recorded for each seedling as follows: $0=$ no evidence of root rot or shoot stunting, 1 = slight tap root discoloration, $2=$ severe stunting or necrosis of tap root and stunting of shoot, and $3=$ plant dead.

Table 1. Isolates of Pythium spp. used in cultural, temperature, and pathogenicity studies

\begin{tabular}{|c|c|c|c|c|c|c|c|}
\hline \multirow[b]{2}{*}{ Isolate } & \multirow[b]{2}{*}{ Morphological spp. } & \multirow[b]{2}{*}{ Host } & \multirow[b]{2}{*}{ Year } & \multirow[b]{2}{*}{ Origin } & \multicolumn{3}{|c|}{ GenBank accession number } \\
\hline & & & & & ITS & $\beta$-Tubulin & $\operatorname{cox} \mathrm{I}$ \\
\hline CBS101876 & Pythium jasmonium & Arabidopsis thaliana & 1998 & Washington, United States & AF216654 & KJ424409 & KJ424404 \\
\hline P1 & P. brassicum & Brassica oleracea (broccoli) & 2011 & California, United States & KJ183088 & KJ183097 & KJ183091 \\
\hline P2 & P. brassicum & B. oleracea (broccoli) & 2011 & California, United States & KJ183089 & KJ183098 & KJ183092 \\
\hline P3 & P. brassicum & B. oleracea (broccoli) & 2011 & California, United States & KJ183090 & KJ183099 & KJ183093 \\
\hline PPRI8402 & P. jasmonium & B. oleracea & 1994 & South Africa & FJ415959 & KJ424412 & KJ424407 \\
\hline PPRI8404 & P. jasmonium & B. napus (canola) & 1994 & South Africa & KJ424403 & KJ424413 & KJ424408 \\
\hline MAFF725020 & P. megalacanthum & B. oleraceae (cabbage) & 2004 & Japan & AB512739 & KJ424410 & KJ424405 \\
\hline MAFF725021 & P. megalacanthum & B. oleraceae (cabbage) & 2004 & Japan & AB512782 & KJ424411 & KJ424406 \\
\hline
\end{tabular}


The polymerase chain reaction (PCR) reaction mixture in $25 \mu \mathrm{l}$ consisted of DNA template (30 ng), $10 \times$ buffer containing $15 \mathrm{mM}$ $\mathrm{MgCl}_{2}$ (Apex; Genesee Scientific), $2.5 \mathrm{mM}$ each dNTP, $2.5 \mu \mathrm{g}$ of bovine serum albumen, $10 \mu \mathrm{M}$ each forward and reverse primers, and $1 \mathrm{U}$ of Apex Taq polymerase (Genesee Scientific). PCR amplification conditions using a PTC-100 thermal cycler (MJ Research) consisted of initial denaturation at $95^{\circ} \mathrm{C}$ for $4 \mathrm{~min}$; followed by 40 cycles of denaturation at $94^{\circ} \mathrm{C}$ for $1 \mathrm{~min}$, primer annealing for $1 \mathrm{~min}$ at $57^{\circ} \mathrm{C}$ for ITS, $52^{\circ} \mathrm{C}$ for coxI, and $63^{\circ} \mathrm{C}$ for $\beta$-tubulin, and extension at $72^{\circ} \mathrm{C}$ for $2 \mathrm{~min}$; with a final extension at $72^{\circ} \mathrm{C}$ for $7 \mathrm{~min}(15)$. PCR products were visualized in $2 \%$ (wt/vol) agarose gels stained with ethidium bromide. Amplification products were purified by ethanol-sodium acetate precipitation. Sequencing of PCR amplicons was carried out using the same forward and reverse primers as described above in a standard Sanger dideoxy sequencing reaction in a 3730 XL DNA analyzer (ABI, Institute for Integrative Genome Biology, UC Riverside).

Sequence analysis. A BLAST search in GenBank for the three gene sequences (ITS, coxI, and $\beta$-tubulin) was done for isolates CBS101876, P1, P2, P3, PPRI8402, PPRI8404, MAFF725020, and MAFF725021 (Table 1). Nucleotide sequences representing various isolates within phylogenetic clade J of Pythium $(5,9)$ with the highest homology to P1 were selected (Table 3) and used in constructing phylogenetic trees using MEGA version 5 (11). Multiple sequence alignment was performed using ClustalW. Phylogenetic relationships among Pythium isolates, based on gene sequences for ITS, coxI, and $\beta$-tubulin, were inferred by maximum parsimony (MP) using the Subtree-Pruning-Regrafting search method of MEGA. Bootstrap 50\% majority-rule consensus trees were generated using 1,000 replications. Phylogenetic trees were constructed for ITS, $\beta$-tubulin, and coxI individually and for the combined dataset of ITS and coxI. Phytophthora megasperma isolate P1278 was used as outgroup for $\beta$-tubulin analysis.

\section{Results}

Isolations from root samples. Diseased broccoli plants were stunted (Fig. 1A) and roots were at various stages of decay. Light microscopy of symptomatic root tissues revealed the presence of numerous large spiny oogonia in cortical tissues (Fig. 1B and C). A Pythium sp. with large spiny oogonia was consistently isolated from necrotic roots of all broccoli plants sampled. One isolate from a plant collected in the North, South, and West portions of the 30ha commercial field (i.e., P1, P2, and P3, respectively) was randomly selected and placed in our culture collection. All isolates were morphologically indistinguishable. Therefore, P1 was selected as representative of the three isolates for most studies.

Morphological characteristics of Pythium isolates. On V8C agar medium, colonies of all isolates from broccoli and the remaining $\mathrm{Pj} 6$ isolates grew with little aerial mycelium and without any special growth pattern, with the exception of isolate CBS101876 that produced clumps of aerial hyphae. All isolates produced spiny oogonia in V8C broth and had coenocytic hyphae 5 to $7.5 \mu \mathrm{m}$ in diameter. Morphometrics of oogonia, oospores, as well as spine height, width, and shape of the Pj6 isolates are presented in Table 4 and illustrated in Figure 2A and B. All isolates were morphologically similar but dimensions of all structures of isolate CBS101876 from Arabidopsis thaliana were smaller. Additionally, spines on oogonia of the latter isolate were less numerous and of varied shapes compared with the other five isolates. Antheridia were bulbous and broadly attached to oogonia and ranged in size from 12.2 by 17.5 to 11.25 by $18.75 \mu \mathrm{m}$. The number of antheridia ranged from 1 to 4 per oogonium for each isolate (Fig. 2A).

None of the isolates produced asexual spores in V8C broth. However, intercalary and terminal sporangia, measuring 25 to 40 $\mu \mathrm{m}$ in diameter, were occasionally observed in water agar adjacent to broccoli roots colonized by P1 and PPRI8404 but rarely by others. When flooded with sterile distilled water and incubated at $25^{\circ} \mathrm{C}$, most sporangia germinated directly within $1 \mathrm{~h}$ with a germ tube (Fig. 2C inset). A few sporangia (fewer than 5\%) germinated indirectly, with a discharge tube culminating in vesicle and zoospore formation (Fig. 2C). Zoospores were 10 to $12.5 \mu \mathrm{m}$ in diameter.

Growth temperature studies. All Pj6 isolates exhibited a similar mycelial growth response for the temperatures evaluated, with an optimum of $25^{\circ} \mathrm{C}$ and a maximum of $35^{\circ} \mathrm{C}$ (Fig. 3). However, there were differences in the mycelial growth rates among the iso-

Table 3. Reference isolates of Pythium spp. with internal transcribed spacer (ITS), $\beta$-tubulin, and cytochrome c oxidase subunit I (coxI) sequence accession numbers obtained from GenBank and used for constructing phylogenetic trees

\begin{tabular}{|c|c|c|c|c|c|c|}
\hline \multirow[b]{2}{*}{ Species } & \multirow[b]{2}{*}{ Isolate } & \multirow[b]{2}{*}{ Isolation host } & \multirow[b]{2}{*}{ Origin (year) } & \multicolumn{3}{|c|}{ Sequence accession number } \\
\hline & & & & ITS & $\beta$-Tubulin & $\operatorname{cox} \mathbf{I}$ \\
\hline Pythium buismaniae & CBS28831 & Chrysanthemum sp. & Netherlands (1999) & AY598659 & - & HQ708737 \\
\hline P. jasmonium & CBS101876 & Arabidopsis mutant & Washington, United States (1998) & AF216654 & _ & 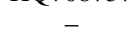 \\
\hline P. jasmonium & DAOM229150 & Arabidopsis mutant & Washington, United States (2010) & - & - & EU350525 \\
\hline P. jasmonium & DAOM 239123 & Arabidopsis mutant & Japan (2007) & - & - & EU350524 \\
\hline P. jasmonium & PRRI8402 & Brassica oleracea & South Africa (2008) & FJ415959 & - & - \\
\hline P. mastophorum & CBS37572 & Apium graveolens & England (2010) & - & - & EU350523 \\
\hline P. megalacanthum & DSMZ62964 & Chrysanthemum sp. & Germany (1999) & AF216660 & - & - \\
\hline P. megalacanthum & DAOM229154 & Not listed & Germany (2010) & HQ643693 & - & HQ708737 \\
\hline P. nodosum & MAFF305905 & Soil & Japan & DQ071346 & - & - \\
\hline P. nunn & ATCC20693 & Soil & Colorado, United States & - & DQ071325 & - \\
\hline P. orthogonon & DS2-6-9D & Zoysia sp. & Japan & - & DQ071329 & - \\
\hline$P$. polymastum & ADC9817 & Not listed & Netherlands (2010) & - & - & HQ708476 \\
\hline$P$. polymastum & CBS81170 & Lactuca sativa & Netherlands (2013) & AY598660 & - & - \\
\hline P. uncinulatum & CBS51877 & L. sativa & Netherlands (2013) & AY598712 & - & AY598712 \\
\hline Pythium sp. & CAL-2011a & - & Washington, United States (2010) & - & - & HQ708819 \\
\hline
\end{tabular}

Table 4. Morphometrics of sexual spores of isolates of Pythium spp. evaluated in this study ${ }^{\mathrm{a}}$

\begin{tabular}{lcccc}
\hline Isolate & Oogonium diameter $(\boldsymbol{\mu m})$ & Oospore diameter $(\boldsymbol{\mu m})$ & Spine height $(\boldsymbol{\mu m})$ & Spine base width $(\boldsymbol{\mu m})$ \\
\hline CBS101876 & $39.2(30.0-46.8)$ & $32.6(26.2-38.2)$ & $6.0(3.7-11.2)$ & $5.1(2.5-7.0)$ \\
P1 & $47.4(37.5-61.6)$ & $37.3(30.0-50.0)$ & $8.5(4.7-16.2)$ & $5.5(1.6-10)$ \\
PPRI8402 & $42.2(35.1-52.5)$ & $33.1(26.5-40.0)$ & $7.7(4.7-15.6)$ & $5.3(3.0-8.6)$ \\
PPRI8404 & $44.6(35.9-57.5)$ & $36.2(28.1-47.5)$ & $6.2(3.9-10.0)$ & $5.2(3.1-7.8)$ \\
MAFF725020 & $42.1(34.3-47.5)$ & $35.1(25.1-42.5)$ & $6.5(3.1-9.5)$ & $5.5(3.1-7.8)$ \\
MAFF725021 & $42.6(32.7-50.0)$ & $34.6(27.3-45.0)$ & $6.1(3.1-11.2)$ & $5.3(3.1-7.8)$ \\
\hline
\end{tabular}

\footnotetext{
${ }^{a}$ Values represent means of 50 measurements from four independent experiments. Numbers in parentheses are the ranges of lowest and highest measure-
} ments. Isolates were cultured in $10 \%$ clarified V8 juice broth. 
lates. CBS101876 and PPRI8402 had the slowest mycelial growth rates at the lower temperatures evaluated.

Pathogenicity tests. In greenhouse tests, broccoli isolate P1 caused stunting and reduction in fresh weight relative to noninoculated controls. Fresh weight of plants was significantly reduced from 16.4 and $23.7 \mathrm{~g}$ in the controls to 6.9 and $12.1 \mathrm{~g}$ in the inoculated treatments after 3 and 4 weeks for experiments 1 and 2, respectively (Fig. 4). Oospores of the pathogen were microscopically observed in necrotic roots and the pathogen was reisolated, thus completing Koch's postulates. Additionally, laboratory tests confirmed the pathogenicity of P1 to broccoli as well as 9 cultivated and 12 noncultivated plant species in the family Brassicaceae but not to 18 species of plants belonging to 11 other plant families (Table 2). Roots of all seedlings in the family Brassicaceae became stunted and necrotic within 7 days and most seedlings died within 10 days after inoculation (Fig. 5). Numerous spiny oogonia were observed in necrotic roots and in agar adjacent to necrotic roots.

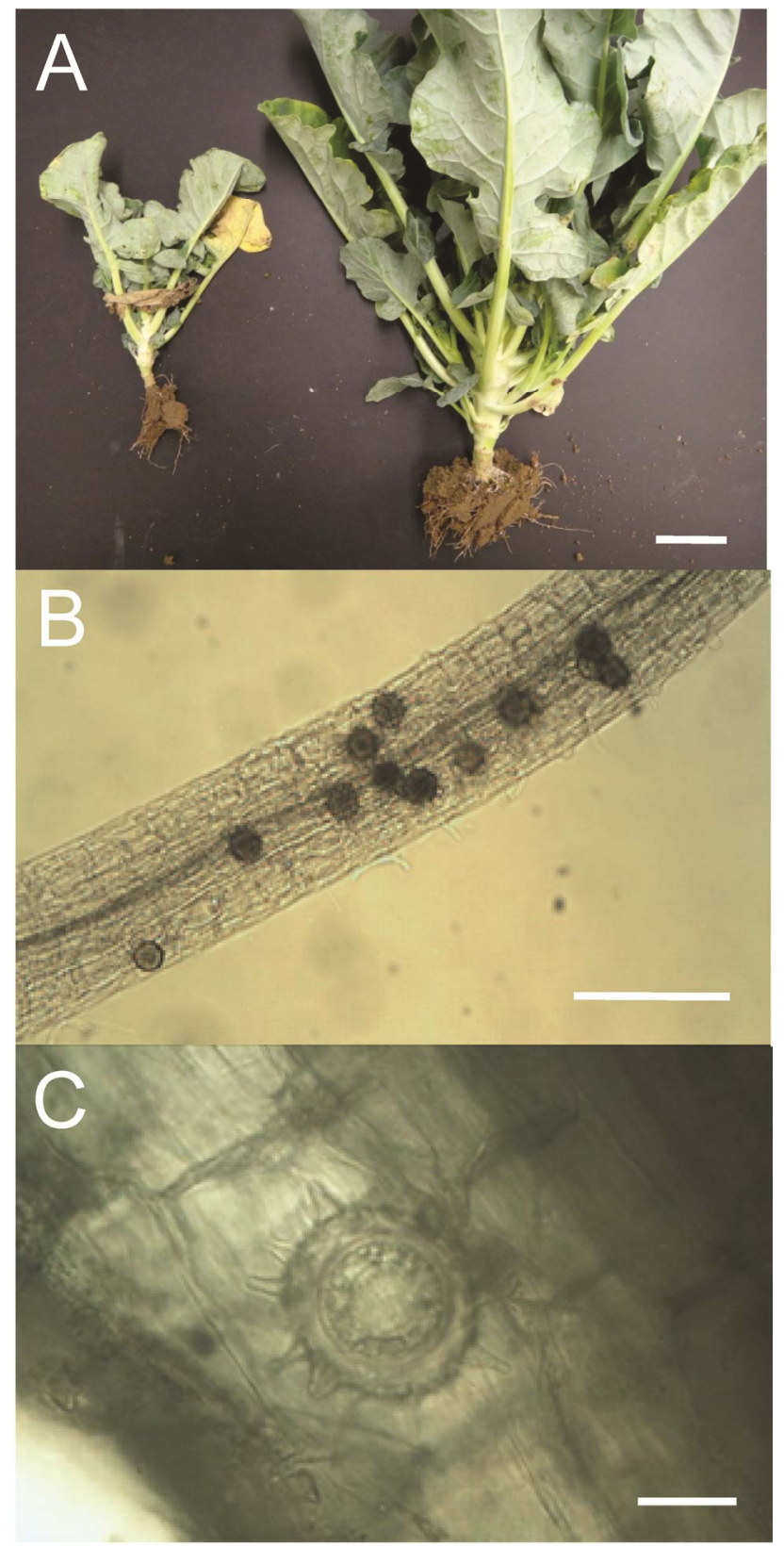

Fig. 1. Broccoli (Brassica oleracea var. italica) plants collected 55 days after seeding in a commercial field in Blythe, California. A, Infected (left) and healthy (right) plants. Bar $=4 \mathrm{~cm} ; \mathrm{B}$, Oospores of Pythium brassicum inside a necrotic root. Bar $=260 \mu \mathrm{m}$; and $\mathbf{C}$, a large spiny oogonium (diameter $=48 \mu \mathrm{m})$ and aplerotic oospore of Pythium brassicum inside a necrotic root. Bar $=25 \mu \mathrm{m}$.
Additionally, sporangia were also observed in agar adjacent to infected roots. Similar to P1, the other five Pj6 isolates and P2 and P3 were pathogenic (disease rating of 3) to broccoli, with significant reductions in stem and root lengths and plant fresh weights (Fig. 6), but not to lettuce or flax. Only an isolate of Pythium polymastum, CBS811.7, was pathogenic (disease rating of 3) to lettuce but not (disease rating of 0 ) to broccoli. All pathogenicity studies were repeated with the same results.

Phylogenetic analysis. Sequences for ITS, coxI, and $\beta$-tubulin genes for all $\mathrm{Pj} 6$ isolates were deposited in GenBank with accession numbers listed in Table 1. Using the MP method on the ITS dataset, Pythium isolates from Japan ( $P$. megalacanthum MAFF725020 and MAFF725021), South Africa ( $P$. jasmonium PPRI8402 and PPRI8404), and the United States ( $P$. jasmonium CBS101876 and our broccoli isolates P1, P2, and P3) grouped

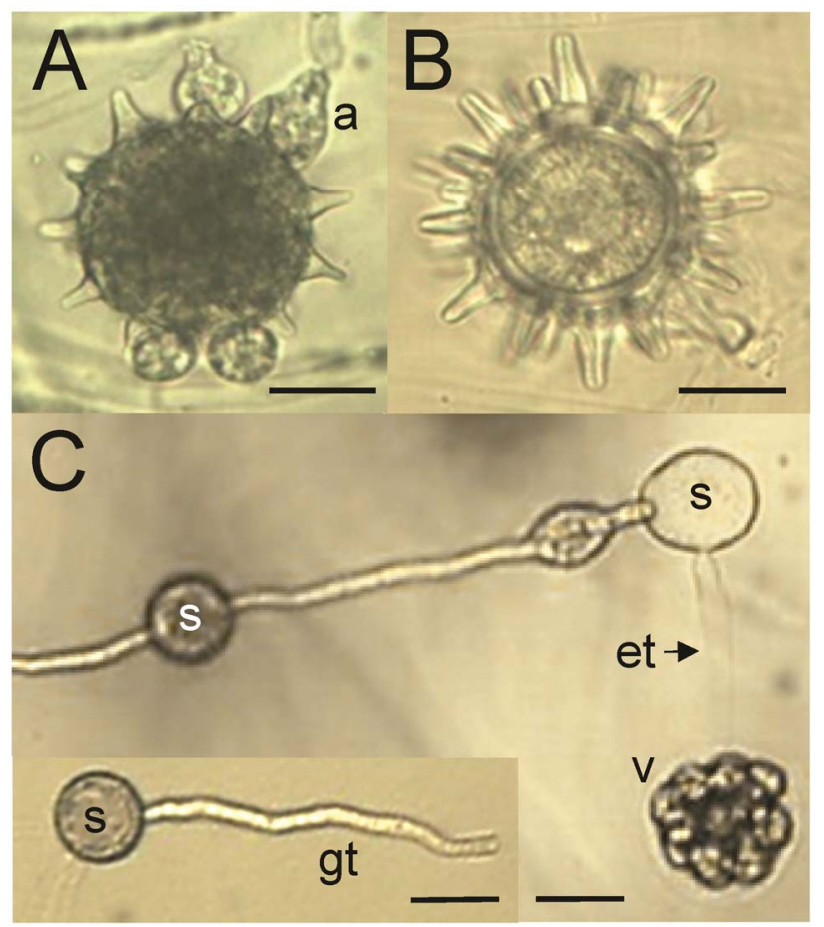

Fig. 2. Sexual and asexual reproductive structures of Pythium brassicum. A, Spiny oogonium with four antheridia (a) attached; B, Spiny oogonium with a mature thickwalled aplerotic oospore. Bars $=30 \mu \mathrm{m}$. C, Intercalary and terminal sporangia (s). The terminal sporangium has germinated indirectly with an evacuation tube (et) and a vesicle (v) with zoospores. Inset: Sporangium germinating directly with a germ tube (gt). Bars $=25 \mu \mathrm{m}$.

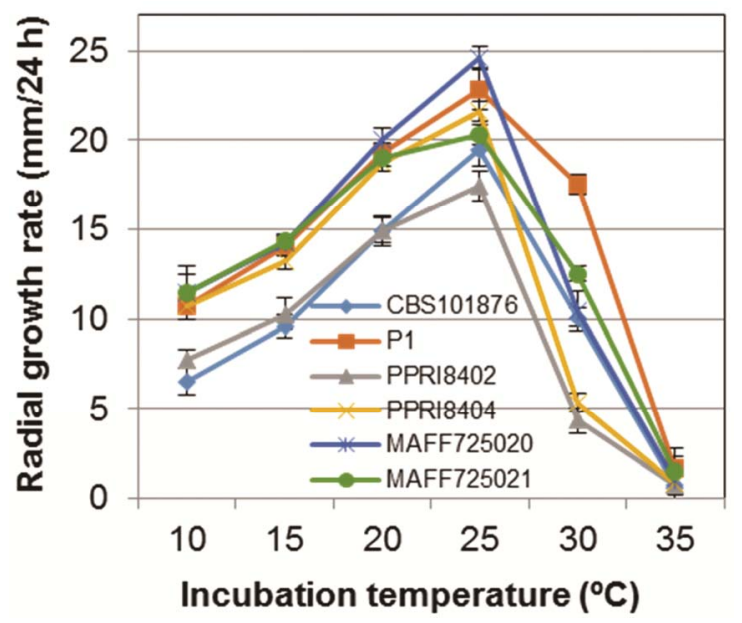

Fig. 3. Growth-temperature relationships of Pythium brassicum isolates. Means of six isolates are from two experiments. 
closely together and formed a distinct cluster separate from other species in subclade B with $100 \%$ bootstrap support (Fig. 7A). The latter species included $P$. mastophorum CBS37572, $P$. uncinulatum CBS51877, P. megalacanthum DAOM229154 and DSMZ62964, $P$. polymastum CBS81170 and ADC9817, and $P$. buismaniae CBS28831. The consistency index (CI) was 0.958084 and the retention index (RI) was 0.987784 .

Analysis of $\beta$-tubulin sequences using MP showed the same clustering of all Pythium isolates from Japan, South Africa, and the United States, with P1, P2, and P3 slightly distant from the rest of the other isolates. The CI and RI values were 0.902913 and 0.782609, respectively. As an outgroup, P. orthogonon DS-2-6-9D,

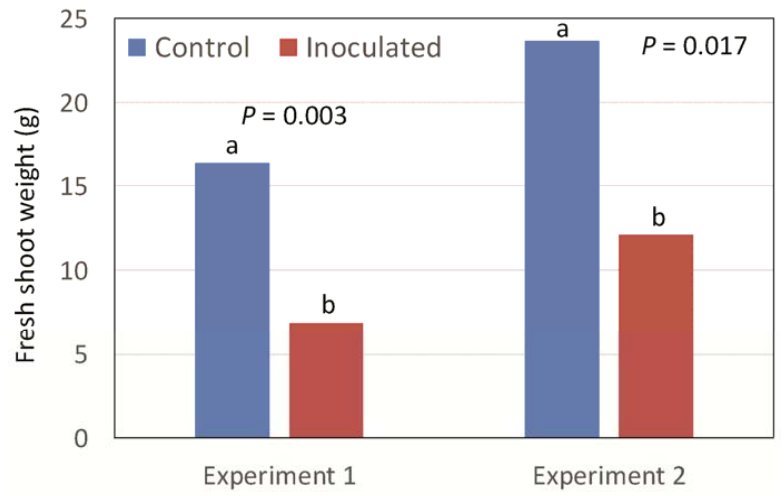

Fig. 4. Fresh shoot weights of broccoli plants 3 and 4 weeks after inoculation with Pythium brassicum (isolate P1). There were four replications of each treatment. Bars within each experiment marked with a different letter differ significantly and $P$ values indicate levels of significance within each experiment.

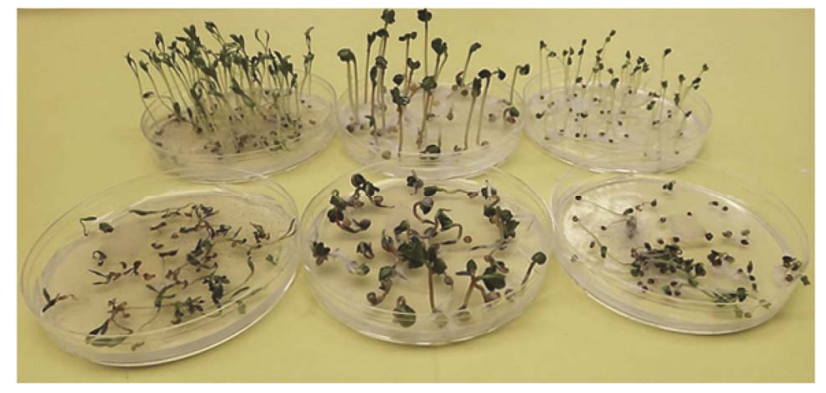

Fig. 5. Pathogenicity tests with Pythium brassicum (isolate P1) on garden cress (left), broccoli (center), and rapini (right) on water agar 7 days after inoculation. Inoculated plants in foreground and respective controls in background.

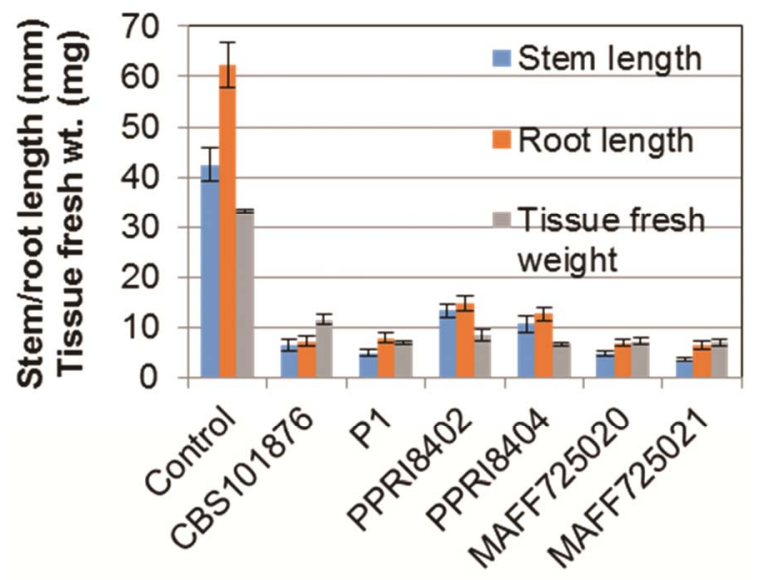

Pythium isolate

Fig. 6. Pathogenicity tests with Pj6 isolates on broccoli seedlings. All isolates significantly reduced stem and root length, and decreased tissue fresh weight 7 days after inoculation compared with the noninoculated control.
P. nodosum MAFF305905, and P. nunn ATCC20694 formed a separate cluster (subgroup A), with $83 \%$ bootstrap support and considerable diversity (Fig. 7B).

Phylogenetic analysis for coxI showed clustering of the $\mathrm{Pj} 6$ isolates, P. jasmonium DAOM229150 and DAOM239123, as well as Pythium sp. CAL2011a (CBS101876), with 100\% bootstrap support. There were slight genetic distances among them. All four Japanese and South African isolates ( $P$. megalacanthum MAFF725020 and MAFF725021 and $P$. jasmonium PPRI8402 and PPRI8404) together with the P. jasmonium isolate from Washington (DOAM 229150), formed a subgroup (77\% bootstrap support)

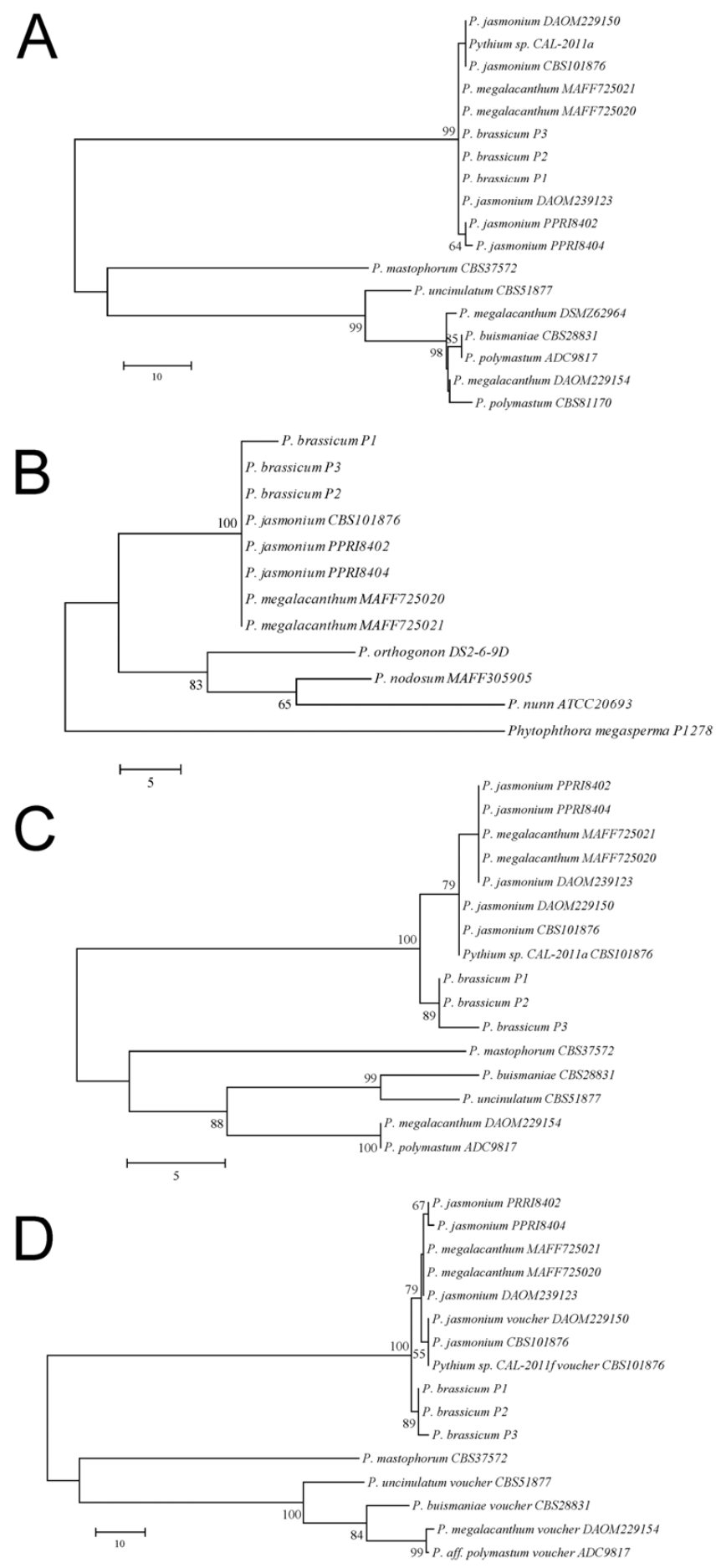

Fig. 7. Phylogenetic analyses of Pythium isolates based on: $\mathbf{A}$, internal transcribed spacer (ITS); B, $\beta$-tubulin; C, coxl; and D, combined ITS and coxl gene sequences using maximum parsimony. Numbers on the branches represent bootstrap values greater than 50 obtained from 1,000 replications. Bars = numbers of substitutions per site. 
distinct from that of P1, P2, and P3 isolates (89\% bootstrap support). The CI and RI values for this MP analysis were 0.904255 and 0.938776, respectively. P. megalacanthum DAOM229154 and $P$. polymastum ADC9817 had identical coxI sequences and grouped distantly with $P$. unicinulatum CBS51877 and P. mastophorum CBS37572 (Fig. 7C).

The topology of combined ITS and coxI gene sequences revealed that the $\mathrm{Pj} 6$ isolates, as well as $\mathrm{P} 1, \mathrm{P} 2$, and $\mathrm{P} 3 ; P$. jasmonium isolates DAOM 229150 and DAOM239123; and Pythium sp. CAL-2011a (CBS101876) constitute a cluster with $100 \%$ bootstrap support within subclade B of clade J, which is distinct from the second cluster of isolates in subclade B represented by $P$. mastophorum, P. buismaniae, $P$. megalacanthum, and $P$. polymastum (Fig. 7D). Genetic differences among Pythium isolates in the first cluster were small, whereas there was much more diversity among isolates in the second cluster. The analysis for combined ITS and coxI sequence data had a CI $=0.941176$ and RI $=0.970954$.

\section{Discussion}

Isolations from diseased roots of stunted broccoli plants yielded a Pythium spp. with distinct morphological characteristics and could not be easily assigned to any known species infecting this crop. The broccoli isolates (e.g., P1, P2, and P3) had 99\% ITS sequence similarity with P. jasmonium (4) and $100 \%$ with two isolates of $P$. megalacanthum (MAFF725020 and MAFF725021). $P$. jasmonium CBS101876 was originally identified as $P$. mastophorum when first recovered from necrotic roots of a jasmonatesuppressed A. thaliana mutant in 1998 (14). Because it had a distinct ITS sequence, it was later designated a new species, $P$. jasmonium $(4,7)$. However, this species has not been formally described and, thus, is an invalid name. A search by us in GenBank indicated that three other accessions carry the specific epithet of $P$. jasmonium (DAOM229150, DAOM239123, and PPRI8402) but were previously identified as either $P$. megalacanthum or $P$. polymastum based upon similar morphological characteristics. Other isolates labeled $P$. megalacanthum (DAOM229154) or $P$. polymastum (ADC9817) grouped into the second cluster of subclade B of clade $\mathrm{J}$ in our molecular analysis (Fig. 7A, C, and D).

Our data support the naming of a new species for all $\mathrm{Pj} 6$ isolates, DAOM229150 and DAOM239123 isolates, and additional isolates from broccoli in California (e.g., P2 and P3) because these isolates all grouped closely together in the phylogenetic analyses of multilocus sequence data. Additionally, these isolates originated from diseased roots of plants in the family Brassicaceae and, as we demonstrated for several of them, are apparently pathogenic only to species in this plant family. The specific epithet "jasmonium", however, is not appropriate because none of the susceptible plants in our study were jasmonate suppressed and, second, the epithet "jasmonium" is an invalid name. Additionally, although two isolates assigned to $P$. megalacanthum are found in the phylogenetic cluster together with the broccoli isolates, this species epithet is also not suitable because another isolate of $P$. megalacanthum (DAOM229154) grouped with the second cluster of species in subclade B of clade J. Thus, we suggest placing $P$. jasmonium in synonymy with a new species, $P$. brassicum, as described below.

Morphological description: Pythium brassicum Stanghellini, Mohammadi, Förster, \& Adaskaveg sp. nov. CBS137315, Holotype, P1, isolated from roots of broccoli, California, USA.

Colonies on clarified V8 juice agar submerged without a special pattern. Main hyphae up to $7.5 \mu \mathrm{m}$ wide. Sporangia globose to irregularly shaped, 25 to $40 \mu \mathrm{m}$ (average $34.5 \mu \mathrm{m}$ ) in diameter, terminal or intercalary. Zoospores (10 to $12.5 \mu \mathrm{m}$ diameter) released from vesicles at $25^{\circ} \mathrm{C}$. Discharge tubes 20 to $200 \mu \mathrm{m}$ in length and 5 to $7 \mu \mathrm{m}$ wide arising from any part of the sporangium. Oogonia mostly terminal on side branches, globose, 37.5 to 61.6 $\mu \mathrm{m}$ (average $47.4 \mu \mathrm{m}$ ) in diameter with numerous spines. Spines mostly conical with blunt tips, 4.7 to $16.2 \mu \mathrm{m}$ (average $8.5 \mu \mathrm{m}$ ) in height, $2 \mu \mathrm{m}$ in diameter at spine tip, and $5.5 \mu \mathrm{m}$ diameter at spine base. Antheridia 1 to 4 , mostly 1 per oogonium, primarily dicli- nous, bulbous, 12.5 to $18.7 \mu \mathrm{m}$ in diameter. Oospores aplerotic, 30 to $50 \mu \mathrm{m}$ (average $37.3 \mu \mathrm{m}$ ) in diameter, wall up to $2.5 \mu \mathrm{m}$ thick. Isolate P1 of P. brassicum is herein designated the holotype and has been deposited at the CBS-KNAW Fungal Biodiversity Center, The Netherlands.

In addition to possession of unique sequences (ITS, $\beta$-tubulin, and $\operatorname{cox} 1)$ that are sufficient to justify status as a new species, spines on oogonia of $P$. brassicum are primarily conical with blunt tips. This is in contrast to spine shapes reported for other species in subclade B $(2,3,8,12)$. Spines of $P$. mastophorum and $P$. polymastum are primarily mammiform with acute tips. Spines of $P$. uncinulatum are curved (resembling rose thorns) with acute tips, and spines of $P$. buismaniae are conical with irregular terminal projections. Spines of $P$. megalacanthum have been reported as conical with acute tips or mammiform.

Host specificity, coupled with distinct molecular characteristics, has been used in naming of a new species of Phytophthora (i.e., Phytophthora brassicae) (6). The concept of a Brassicaceae-family-specific species of Pythium is not new. In 1974, Vanterpool reported on the host-specificity of a "Brassica strain of $P$. polymastum" (13). The morphological characteristics and host range of his isolates closely resemble those we recovered from broccoli. Unfortunately, a culture of his isolate that was deposited in the culture collection of CMI (IMI173501) is no longer available.

Whereas crop rotation is generally not a recommended management strategy for Pythium spp. because these pathogens generally have wide host ranges, the existence of host specificity (i.e., Pythium brassicum) indicates that rotation with non-Brassicaceae plants and management of weeds belonging to this plant family could be efficacious in disease management.

\section{Acknowledgments}

We thank A. McLeod and W. Botha, South Africa; M. Kubota and K. Kageyama, Japan; and M. Coffey, University of California, Riverside, for providing cultures of $P$. jasmonium (PPRI8402 and PPRI8404), P. megalacanthum (MAFF725020 and MAFF725021), and P. polymastum (CBS811.7), respectively; M. Coffey for providing importation permits of the above cultures; and J. DiTomaso, UC Davis, for providing the seed of the noncultivated plants in the family Brassicaceae.

\section{Literature Cited}

1. Aegerter, D. J., and Davis, R. M. 1998. First report of Pythium polymastum on broccoli and cauliflower in California. Plant Dis. 82:1282.

2. de Bary, A. 1881. Zur Kenntniss der Peronosporeen. Bot. Z. 39:539-544.

3. Drechsler, C. 1939. Three species of Pythium with large oogonial protuberances. Phytopathology 29:1005-1031.

4. Jackson, C. A. R., De Cock, A. W. A. M., Vijayan, P., and Lévesque, C. A. 2000. Pythium jasmonium, a new species with ornamented oogonia from a jasmonate-deficient Arabidopsis mutant. Can. J. Plant Pathol. 22:178.

5. Lévesque, C. A., and De Cock, A. W. A. M. 2004. Molecular phylogeny and taxonomy of the genus Pythium. Mycol. Res. 108:1363-1383.

6. Man in't Veld, W. A., de Cock, A. W. A. M., Ilieva, E., and Lévesque, C. A 2002. Gene flow analysis of Phytophthora porri reveals a new species: Phytophthora brassicae sp. nov. Eur. J. Plant Pathol. 108:51-62.

7. McLeod, A., Botha, W. J., Meitz, J. C., Spies, C. F. J., Tewoldemedhin, Y. T., and Mostert, L. 2009. Morphological and phylogenetic analyses of Pythium species in South Africa. Mycol. Res. 113:933-951.

8. Middleton, J. T. 1943. The taxonomy, host range and geographical distribution of the genus Pythium. Mem. Torrey Bot. Club 20:1-171.

9. Robideau, G. P., De Cock, A. W. A. M., Coffey, M. D., Voglmayr, H., Brouwer, H., Bala, K., Chitty, D. W., Désaulniers, N., Eggertson, Q. A., Gachon, C. M. M., Hu, C.-H., Küpper, F. C., Rintoul, T. L., Sarhan, E., Verstappen, E. C. P., Zhang, Y., Bonants, P. J. M., Ristaino, J. B., and Lévesque, A. C. 2011. DNA barcoding of oomycetes with cytochrome $c$ oxidase subunit I and internal transcribed spacer. Mol. Ecol. Resour. 11:10021011.

10. Schroeder, K. L., Martin, F. N., de Cock, A. W. A. M., Lévesque, C. A. Spies, C. F. J., Okubara, P. A., and Paulitz, T. C. 2013. Molecular detection and quantification of Pythium species: Evolving taxonomy, new tools, challenges. Plant Dis. 97:4-20.

11. Tamura, K., Peterson, D., Peterson, N, Stechey, G., Nei, M., and Sudhir, K 2011. MEGA5: Molecular evolutionary genetics analysis using maximum likelihood, evolutionary distance, and maximum parsimony methods. Mol. Biol. Evol. 28:2731-2739.

12. Van der Plaats-Niterink, A. J. 1981. Monograph of the genus Pythium. Stud. Mycol. No. 21.

13. Vanterpool, T. C. 1974. Pythium polymastum pathogenic on oilseed rape 
and other crucifers. Can. J. Bot. 52:1205-1208.

14. Vijayan, P., Shockey, J., Lévesque, C. A., Cook, R. J., and Browse, J. 1998. A role for jasmonate in pathogen defense of Arabidopsis. Proc. Natl. Acad. Sci. USA 95:7209-7214.

15. Villa, N. O., Kageyama, K., Asano, T., and Suga, H. 2006. Phylogenetic relationships of Pythium and Phytophthora species based on ITS rDNA, cytochrome oxidase II and $\beta$-tubulin gene sequences. Mycologia 98:410422
16. White, T. J., Bruns, T., Lee, S., and Taylor, J. W. 1990. Amplification and direct sequencing of fungal ribosomal RNA genes for phylogenetics. Pages 315-322 in: PCR Protocols: A Guide to Methods and Applications. M. A. Innis, D. H. Gelfand, J. J. Sninsky, and T. J. White, eds. Academic Press, Inc., New York.

17. Zelaya-Molina, L. X., Ortega, M. A., and Dorrance, A. E. 2011. Easy and efficient protocol for oomycete DNA extraction suitable for population genetic analysis. Biotechnol. Lett. 33:715-720. 